\title{
Antimicrobial Therapy for Community-Acquired Pneumonia in Adults
}

\author{
Clovis Arns da Cunha, Helio S. Sader, Antonio C. Nicodemo \\ and Brazilian Society for Infectious Diseases Practice \\ Guidelines Committee
}

\author{
Federal University of Paraná, Infectious \\ Diseases Service of the Nossa Senhora das \\ Graças Hospital, Curitiba, Paraná; Federal \\ University of São Paulo/EPM; University of \\ São Paulo, SP, Brazil
}

This is part of the series of practice guidelines commissioned by the Brazilian Society for Infectious Diseases through its Practice Guidelines Committee. The purpose of these guidelines is to provide assistance to clinicians in the antimicrobial treatment of community-acquired pneumonia (CAP) in immunocompetent adults. Panel members and consultants are experts in adult infectious diseases. The guidelines are evidence based where possible. The recommendations included in this document were elaborated based on the most frequently isolated pathogens and their antimicrobial susceptibilities. The etiology was based mainly on international studies, since there are very few regional data. On the other hand, the antimicrobial susceptibilities of main bacterial causes of CAP were based on the results of several antimicrobial resistance surveillance studies recently performed in Brazil. Other reference guidelines for the treatment of CAP, such as those elaborated by the Infectious Diseases Society of America and by the Canadian Infectious Diseases Society, were also discussed by the group during the elaboration of this document.

Key Words: Community-Acquired Pneumonia, guidelines, Brazilian Society for Infectious Diseases.

Lower respiratory tract infection is a major cause of death due to infectious diseases. Despite substantial progress in the detection of pathogens and in therapeutic options, there continue to be major controversies in the clinical management of these infections. The etiological diagnosis is made only in a very small percentage of the cases of community-acquired pneumonia (CAP). Thus, antimicrobial therapy is empirical in the vast majority of cases, and should be based on local epidemiological and surveillance studies.

Pneumonia should be suspected in patients with newly acquired lower respiratory symptoms (cough, sputum production, and/or dyspnea), especially if these Received on 8 November 2001; revised 15 February 2002. Address for correspondence: Dr. Hélio S. Sader. Disciplina de Doenças Infecciosas e Parasitárias. Universidade Federal de São Paulo - EPM. Rua Botucatu, 740, São Paulo, SP - Zip code: 04023.900. Phone/Fax:(11) 5081-2819/5081-2965 / 55715180. E-mail: heliosader@uol.com.br

The Brazilian Journal of Infectious Diseases 2002;6(2):82-87 (C) 2002 by The Brazilian Journal of Infectious Diseases and Contexto Publishing. All rights reserved.

$1413-8670$ symptoms are accompanied by fever, altered breath sounds, and rales. It is recognized that there must be a balance between reasonable diagnostic procedures and empiric therapy. The importance of establishing the diagnosis of pneumonia and its cause is heightened with the increased concern on overuse of antibiotics.

Diagnosis of CAP is based on an analysis of clinical and laboratory data, including chest radiography and microbiological data. The differential diagnosis includes infectious and noninfectious causes. The main examples of noninfectious causes are reactive airways disease, atelectasis, congestive heart failure, bronchiolitis obliterans with organizing pneumonia (BLOOP), vasculitis, pulmonary embolism, and pulmonary malignancy. Among the infectious causes, most upper respiratory tract infections and acute bronchitis are of viral origin, do not require antimicrobial therapy, and are the motive of considerable antibiotic abuse [Bartlet et al., 1998; Bartlet et al., 2000; Mandell et al., 2000; Nakatani et al., 2001] 
Recommendations regarding the decision for hospitalization are based on the methodology used in the clinical prediction rule for short-term mortality, from the publications of the Pneumonia Patient Outcome Research Team (Pneumonia PORT)(Table 1)[Fine et al., 1997]. The Pneumonia PORT prediction rule is based on the evaluation of 14,199 inpatients with CAP. It was independently validated with 38,039 inpatients with CAP and 2,287 inpatients and outpatients prospectively enrolled in the Pneumonia PORT cohort study. With this rule, patientsare stratified into 5 severity classes by means of a 2-step process. In step 1, patients are classified as riskclass I (the lowest severity level) if they are $<50$ years old, have none of 5 important comorbid conditions (neoplastic disease, liver disease, congestiveheart failure, cerebrovascular disease, or renal disease), and have normal or only mildly deranged vital signs' as well as normal mental status. In step 2, all patients who are not assigned to risk class I on the basis of the initial history and physical examination findings alone are stratified intoclasses II-V, on the basis of points assigned for 3 demographic variables (age, sex, and nursing home residence), 5 comorbid conditions (listed above), 5 physical examination findings (alteredmental status, tachypnea, tachycardia, systolic hypotension, hypothermia, or hyperthermia), and 7 laboratory or radiographic findings (acidemia, elevated blood urea nitrogen, hyponatremia, hyperglycemia, anemia, hypoxemia, or pleural effusion - Table 1). Point assignments correspond with the following classes: $<70$, class II; 71-90, class III; 91-130, class IV; and >130, class V [Fine et al., 1997].

Patients in riskclasses I and II do not usually require hospitalization, those in risk class III may require brief hospitalization, and thosein risk classes IV and V usually requirehospitalization. Social factors, such as outpatient supportmechanisms and probability ofadherence, are not included in this assessment.

Prospective studies for evaluating the causes of CAP in adults have failed to identify the cause of $40 \%$ to $60 \%$ of cases, and two or more etiologies have been identified in 2-5\% of cases [Bartlett et al., 1998, Bartlet et al., 2000; Fang et al., 1990; Rocha et al., 2000; British Thoracic Society, 1993]. The most common etiological agent in virtually all studies of CAP is Streptococcus pneumoniae; this agent accounts for approximately two-thirds of all cases of bacteremic pneumonia [Fine et al., 1996]. Other less frequently implicated bacterial pathogens include Haemophilus influenzae (with increasing prevalence of sorotypes other than type B), Mycoplasma pneumoniae, Chlamydia pneumoniae, Staphylococcus aureus, Moraxella catarrhalis, Klebsiella pneumoniae and other Gramnegative rods, and Legionella species. Thus, our recommendations for antimicrobial therapy of CAP are based on the antimicrobial susceptibility of these pathogens and regional data were used when available [Brandileone et al., 1998; Critchley et al., 2001; Sader et al., 2001]. Other non-bacterial causes of CAP include influenza virus, respiratory syncytial virus, adenovirus, parainfluenza virus, and other microbes.

The guidelines for antimicrobial therapy ofCAP should be revised periodically due to the continuing disclosure of new clinical and epidemiological data, including:

a) No convincing association has been demonstrated between individual symptoms, physical findings or laboratory test results, and specific etiology [Bartlett et al., 1998; Rocha et al., 2000; Fang et al., 1990]. Even time-honored beliefs (e.g. the absence of a productive cough or lack of inflammatory sputum suggests etiologies such as species of Mycoplasma, Legionella, and Chlamydia) have not withstood close inspection [Bartlett et al., 1998; Bartlett et al., 2000; Fine et al., 1996; Mandell et al., 2000]. On the other hand, most comparisons have involved relatively small numbers of patients and the potential for separating causes by using constellations of symptoms and physical findings has not been evaluated;

b) The development of newer macrolides with better pharmacokinetic/pharmacodynamic characteristics and fewer adverse effects when compared to erythromycin, such as azithromycin and clarithromycin;

c) The development of newer fluoroquinolones more potent against Streptococcus pneumoniae and some atypical pathogens, such as Mycoplasma pneumoniae 
and Chlamydia pneumoniae, such as levofloxacin, gatifloxacin, and moxifloxacin [Nicodemo et al., 2000; Nicodemo et al., 2001].

Penicillin-resistance among $S$. pneumoniae is of great concern worldwide. However, in Brazil the rates of high level resistance ( $\mathrm{MIC},>2 \mathrm{mg} / \mathrm{mL}$ ) are still low ( $2 \%$ to $4 \%$ ). This pathogen should be continuously monitored in order to detect changes in its antimicrobial susceptibility pattern. In $H$. influenzae, penicillin resistance rates are around $10 \%$ to $12 \%$ [Critchley et al., 2001; Sader et al., 2000; Sader et al., 2001].

Antimicrobial therapy should be chosen based on four main factors: in vitro activity spectrum, adverse reactions, regimen, and cost. Similar to established guidelines, we divided the patients into four groups based on the severity of the infections and the characteristics of the patient (PORT risk classes - Table 1).

\section{A-Patients that do not require hospitalization and have no severity risk factors (PORT risk class I)}

Preferred antimicrobial agents (no order of preference):

- Amoxicillin; or

- Macrolide (azithromycin or clarithromycin or erythromycin); or

- Fluoroquinolones ${ }^{\mathrm{a}}$ with enhanced anti-pneumococci activity (gatifloxacin or levofloxacin or moxifloxacin).

Alternatives:

- Cefpodoxime, cefuroxime, cefprozil, amoxicillinclavulanate acid, tetracycline ${ }^{\mathrm{b}}$, doxycycline ${ }^{\mathrm{b}}$.

Notes:

${ }^{a}$ The newer fluoroquinolones with enhanced antipneumococci activity (gatifloxacin or levofloxacin or moxifloxacin) should be used with caution to avoid rapid increases in resistance rates.

b The tetracyclines were NOT included in the "preferred antimicrobial agents" list due to high rates of resistance $>20 \%$ in Brazil [Sader et al., 2001].

Trimethoprim/sulfamethoxazole is not recommended due to high rates of resistance among
S. pneumoniae (38.6 - 39.8\%) and H. influenzae $(40.1 \%$ to $44.9 \%)$ in Brazil [Sader et al., 2001; Critchley et al., 2001].

Cephalosporins with low anti-pneumococcal activity, such as cefalexin, cefaclor, cefixime, and cefadroxil, are not recommended.

\section{$B$ - Patients that do not require hospitalization but present severe risk factors (PORT risk class II)}

Preferred antimicrobial agents (no order of preference):

- Fluoroquinolone with anti-pneumococci activity (gatifloxacin or levofloxacin or moxifloxacin); or

- Amoxicillin/clavulanate or a cephalosporin (second or third-generation: cefpodoxime or cefuroxime or cefprozil) plus a macrolide (azithromycin, clarithromycin or erythromycin) when there is a chance of pneumonia caused by "atypical" pathogens (Chlamydia pneumoniae, Legionella species or Mycoplasma pneumoniae) $)^{\mathrm{a}}$.

Note:

a The differentiation between CAP caused by "typical" and "atypical" pathogens is extremely difficult based only on clinical symptoms, physical findings, and chest radiography.

C - Therapeutic recommendation for patients that require hospitalization in a general medical ward (risk classes III and IV)

Preferred antimicrobial (no order of preference):

- Intravenous ceftriaxone or cefuroxime plus IV azithromycin or clarithromycin when there is suspicion of "atypical" pneumonia.

- Intravenous fluoroquinolone (gatifloxacin or levofloxacin).

Alternatives:

- Amoxicillin/clavulanate or ampicillin/sulbactam ${ }^{\mathrm{a}}$. 
Table 1. Pathogens most frequently associated with community-acquired pneumonia in adults according to the therapeutic grouping used in the present guideline

\begin{tabular}{|c|c|c|}
\hline Group & Characteristics & Most frequent pathogens \\
\hline$A$ & $\begin{array}{l}\text { - Mild or moderate clinical symptoms } \\
\text { - No need for hospitalization } \\
\text { - Less than } 50 \text { years of age } \\
\text { - No comorbidity }{ }^{a} \\
\text { - Respiratory virus }\end{array}$ & $\begin{array}{l}\text { - Streptococcus pneumoniae } \\
\text { - Mycoplasma pneumoniae } \\
\text { - Chlamydia pneumoniae } \\
\text { - Haemophilus influenzae }\end{array}$ \\
\hline$B$ & $\begin{array}{l}\text { - Mild or moderate clinical symptoms } \\
\text { - No need for hospitalization } \\
\text { - More than } 50 \text { years of age and/or comorbidity }{ }^{a} \\
\text { - Gram-negative rods } \\
\text { - Staphylococcus aureus }\end{array}$ & $\begin{array}{l}\text { - Streptococcus pneumoniae } \\
\text { - Haemophilus influenzae } \\
\text { - Respiratory virus }\end{array}$ \\
\hline$C$ & $\begin{array}{l}\text { - Hospitalization in a general ward } \\
\text { - Haemophilus influenzae } \\
\text { - Gram-negative rods } \\
\text { - Legionella spp. } \\
\text { - Chlamydia pneumoniae }\end{array}$ & - Streptococcus pneumoniae \\
\hline$D$ & $\begin{array}{l}\text { - Hospitalization in an intensive care unit } \\
\text { - Legionella spp. } \\
\text { - Gram-negative rods } \\
\text { - Mycoplasma pneumoniae } \\
\text { - Respiratory virus }\end{array}$ & - Streptococcus pneumoniae \\
\hline
\end{tabular}

a Neoplastic disease, liver disease, congestive heart failure, cerebrovascular disease, renal disease, diabetes mellitus, obstructive lung disease, alcoholism.

Notes:

- ampicillin/sulbactam can be used in this group of patients; however, we suggest reserving this antimicrobial agent mainly to treat infections caused by multiple-drug resistant Acinetobacter spp.

- When there is suspicion of aspiration or when anaerobic bacteria are suspected as the cause of pneumonia (in alcoholized patients, or the elderly with altered mental status) the addition of a drug to treat (cover) anaerobic bacteria such as clindamycin or monotherapy with ampicillin/sulbactamoramoxicillin/ clavulanate, is necessary.

\section{D - Therapeutic recommendation for patients that require hospitalization in an intensive care unit (risk classes IV and V)}

Preferred antimicrobial agents:

- Third- or fourth-generation cephalosporins ${ }^{\text {a }}$ plus IV azithromycin or clarithromycin; or

Alternative:

- Fluoroquinolones ${ }^{b}$ with enhanced antipneumococci activity (gatifloxacin or levofloxacin or moxifloxacin); or 
Table 2. Scoring system for step 2 of the prediction rule: assignment to risk classes II-V (adapted from Bartlett et al. [2000])

\begin{tabular}{|c|c|}
\hline Patient characteristic & Points assigned $^{a}$ \\
\hline \multicolumn{2}{|l|}{ Demographic factor - Age } \\
\hline Male & No. of years of age \\
\hline Female & No. of years of age - 10 \\
\hline Nursing home resident & +10 \\
\hline \multicolumn{2}{|l|}{ Comorbid illnesses } \\
\hline Neoplastic disease $^{\mathrm{b}}$ & +30 \\
\hline Liver disease $^{c}$ & +20 \\
\hline Congestive heart failure $^{\mathrm{d}}$ & +10 \\
\hline Cerebrovascular disease ${ }^{\mathrm{e}}$ & +10 \\
\hline Renal disease $^{f}$ & +10 \\
\hline \multicolumn{2}{|l|}{ Physical examination finding } \\
\hline Altered mental status ${ }^{\mathrm{g}}$ & +20 \\
\hline Respiratory rate $>30$ breaths/min & +20 \\
\hline Systolic blood pressure $<90 \mathrm{~mm} \mathrm{Hg}$ & +20 \\
\hline Temperature $<35^{\circ} \mathrm{C}$ or $>40^{\circ} \mathrm{C}$ & +15 \\
\hline Pulse $>125$ beats $/ \mathrm{min}$ & +10 \\
\hline \multicolumn{2}{|l|}{ Laboratory or radiographic finding } \\
\hline Arterial $\mathrm{pH}<7.35$ & +30 \\
\hline Blood urea nitrogen $>30 \mathrm{mg} / \mathrm{dL}$ & +20 \\
\hline Sodium $<130 \mathrm{mEq} / \mathrm{L}$ & +20 \\
\hline Glucose $>250 \mathrm{mg} / \mathrm{dL}$ & +10 \\
\hline Hematocrit $<30 \%$ & +10 \\
\hline Arterial partial pressure of oxygen $<60 \mathrm{~mm} \mathrm{Hg}^{\mathrm{h}}$ & +10 \\
\hline Pleural effusion & +10 \\
\hline
\end{tabular}

${ }^{a}$ A total point score for a given patient is obtained by adding the patient's age in years (age-10, for females) and the points for each applicable patient characteristic. Points assigned to each predictor variable were based on coefficients obtained from the logistic regression model used in step 2 of the prediction rule.

${ }^{\mathrm{b}}$ Any cancer except basal or squamous cell cancer of the skin that was active at the time of presentation or diagnosed within 1 year of presentation.

${ }^{c}$ A clinical or histological diagnosis of cirrhosis or other form of chronic liver disease such as chronic active hepatitis.

d Systolic or diastolic ventricular dysfunction documented by history and physical examination, as well as chest radiography, echocardiography, scanning, or left ventriculography.

${ }^{\mathrm{e}}$ A clinical diagnosis of stroke, transientischemic attack, or stroke documented by MRI or computed axial tomography.

${ }^{f}$ A history of chronic renal disease or abnormal blood urea nitrogen and creatinine values documented in the medical record.

${ }^{\mathrm{g}}$ Disorientation (to person, place, or time, not known to be chronic), stupor, or coma.

${ }^{\mathrm{h}}$ In the Pneumonia Patient Outcome Research Team cohort study, an oxygen saturation value $<90 \%$ on pulse oximetry or intubation before admission was also considered abnormal. 
Notes:

${ }^{a}$ Ceftazidime is not recommended due to its low activity against Gram-positive bacteria, especially S. pneumoniae and $S$. aureus, when compared to other third-generation cephalosporins such as ceftriaxone and cefotaxime;

${ }^{\mathrm{b}}$ Clinical experience with the use of these new fluoroquinolones in the treatment of pneumonia in the ICU is still limited.

Rifampin can be added when Legionella species is suspected.

Oxacillin may replace either regimen when oxacillinsusceptible $S$. aureus is diagnosed as the cause of infections; however, both regimens provide adequate coverage for this pathogen.

Vancomycin should be added when oxacillinresistant $S$. aureus is suspected. Other options are linezolid and quinopristin/dalfopristin.

Fourth-generation cepholosporins and/or ciprofloxacin and/or an aminoglycoside can be added when Pseudomonas aeruginosa is suspected due to high rates of antimicrobial resistance. P. aeruginos a pneumonia can be treated with drug combinations, but the isolate should be susceptible to the antimicrobial agents used.

\section{Brazilian Society for Infectious Diseases Practice} Guidelines Committee: Adauto Castelo Filho, Antonio C. Nicodemo, Antonio C. Pignatari, Beatriz S. Dias, Carlos A. P. Pereira, Clóvis Arns Cunha, Eduardo A. S. Medeiros, Edwal A. C. Rodrigues, Guido C. Levi, Helio S. Sader, Helio Vasconcellos Lopes, Nanci Silva, Plinio Trabasso, Renato S. Grimbaum e Walter Tavares.

\section{References}

1. Bartlett J.G., Breiman R.F., Mandell L.A., File Jr. T.M. Community-acquired pneumonia in adults: guidelines for management. Clin Infect Dis 1998;26:811-38.

2. Bartlett J.G., Dowell S.F., Mandell L.A., et al. Practice guidelines for the management of community-acquired pneumonia in adults. Clin Infect Dis 2000;31:347-82.

3. Brandileone M.C., Di Fabio J.L., Vieira V.S.D., et al. Geographic distribution of penicillin resistance of Streptococcus pneumoniae in Brazil: Genetic relatedness. Microbial Drug Resist 1998;4:209-17.
4. Critchley Blosser R.S., Karlowsky J.A., Yamakita J., et al. Antimicrobial Resistance in Respiratory Pathogens Isolated in Brazil during 1999-2000. Braz J Infect Dis 2001 [in press].

5. Fang G.D., Fine M., Orloff J., et al. New and emerging etiologies for community-acquired pneumonia with implications for therapy; a prospective multicenter study of 359 cases. Medicine (Baltimore) 1990;69:307-16.

6. Fine M.J., Auble T.E., Yealy D.M., et al. A prediction rule to identify low-risk patients with community-acquired pneumonia. N Engl J Med 1997;336:243-50.

7. Fine M.J., Smith M.A., Carson C.A., et al. Prognosis and outcomes of patients with community acquired pneumonia. JAMA 1996;275:134-41.

8. Mandell L.A., Marrie T.J., Grossman R.F., et al. Canadian guidelines for the initial management of communityacquired pneumonia: an evidence-based update by the Canadian Infectious Diseases society and the Canadian Thoracic Society. Clin Infect Dis 2000;31:383-421.

9. Nakatani J., Rocha R.T., Holanda M.A. Pneumonias adquiridas na comunidade e no hospital. In: Prado F.C., Ramos J., Valle J.R. (eds). Atualização terapêutica. Artes Médicas, São Paulo, 2001.

10. Nicodemo A.C., Nicodemo E.L., Idrahim K.Y. Oral Levofloxacin in the treatment of community-acquired pneumonia. Braz J Infect Dis 2000;4:61-6.

11. Nicodemo A.C., Mendes C.M.F., Oplustil C.P., Sinto S. In vitro activity of fluoroquinolones (gatifloxacin, levofloxacin, and trovafloxacin) and seven other antibiotics against Streptococcus pneumoniae. Braz J Infect Dis 2001;4:50-2.

12. Rocha R.T., Vital A.C. ,Silva C.O.S., et al. Pneumonia adquirida na comunidade em pacientes tratados ambulatorialmente: aspectos epidemiológicos, cínicos e radiológicos das pneumonias atípicas e não atípicas. J Pneumol 2000; 1:5-14.

13. Sader H.S., Gales A.C., Granacher T.L., et al. Prevalence of antimicrobial resistance among respiratory tract isolates in Latin America: Results from SENTRY Antimicrobial Surveillance Program (1997-98). Braz J Infect Dis 2000; 4:246-55.

14. Sader H.S., Gales A.C., Reis A.O., et al. Sensibilidade a antimicrobianos de bactérias isoladas do trato respiratório de pacientes com infecções respiratórias adquiridas na comunidade: resultados brasileiros do Programa SENTRY de Vigilância de Resistência a Antimicrobianos dos anos de 1997 e 1998. J Pneumol 2001;27:25-34.

15. The British Thoracic Society. Guidelines for the management of community-acquired pneumonia in adults admitted to hospital. Br J Hosp Med 1993;49:346-50. 